\title{
An integrated mechanical-enzymatic reverse osmosis treatment of dairy industry wastewater and milk protein recovery as a fat replacer: a closed loop approach
}

\author{
F. Sarghini, ${ }^{1}$ A. Sorrentino, ${ }^{1}$ P. Di Pierro \\ ${ }^{1}$ Department of Agriculture, University of Naples Federico II , Portici (NA), Italy; Department of \\ Chemical Sciences, University of Naples Federico II , Portici (NA), Italy
}

\begin{abstract}
The dairy industry can be classified among the most polluting of the food industries in volume in regard to its large water consumption, generating from 0.2 to $10 \mathrm{~L}$ of effluent per liter of processed milk. Dairy industry effluents usually include highly dissolved organic matter with varying characteristics, and a correct waste management project is required to handle. In a framework of natural water resource availability and cost increase, wastewater treatment for water reuse can lower the overall water consumption and the global effluent volume of industrial plants. Moreover, correct dismissal of dairy industry wastewater is sometimes neglected by the operators, increasing the environmental impact due to the chemical and biological characteristics of such effluents. On the other hand, in the case of whey effluents, several by-products are still present inside, such as lactose and milk proteins. Membrane technology has some advantages including a high degree of reliability in removing dissolved, colloidal and particulate matter, like the selectivity in size of pollutants to be removed and the possibility of very compact treatment plants. For example, Reverse Osmosis (R0) technology has been successfully applied for the treatment of dairy wastes (1), and as a technology for concentration and fractionation of whey. In this work a membrane treatment approach using reverse osmosis technology is investigated and implemented: the permeate obtained can be reused as clean warm water for cleaning and sanitation of production plants, while concentrated milk proteins are modified by using transglutaminase enzyme obtaining a high temperature
\end{abstract}

Correspondence: Fabrizio Sarghini, DIAAT, Via Università, $100-80055$ Portici (NA), Italy.

E-mail: sarghini@unina.it

Key words: dairy industry waste recovery, enzymatic treatment, low fat mozzarella cheese, whey.

Acknowledgements: Regione Campania, PSR 2007-2014 under 1.2.4 program is gratefully acknowledged for financial support.

(C) Copyright F. Sarghini et al., 2013

Licensee PAGEPress, Italy

Journal of Agricultural Engineering 2013; XLIV(s2):e57

doi:10.4081/jae.2013.s2.e57

This article is distributed under the terms of the Creative Commons Attribution Noncommercial License (by-nc 3.0) which permits any noncommercial use, distribution, and reproduction in any medium, provided the original author(s) and source are credited. resistant fat replacer to be used in different low-fat products like for example mozzarella cheese.

\section{Introduction}

The dairy industry produces an high amount of wastewaters characterized by a severe chemical oxygen demand (COD) and biological oxygen demand (BOD) representing their high organic content (Orhon et al, 1993). Furthermore, the dairy industry is one of the largest sources of industrial effluents in Europe: a typical European dairy industry generates a large amount of effluent ranging from 0.2 to $10 \mathrm{~L}$ per liter of processed milk.

Dairy waste effluents are usually concentrated, and the main contributors of organic load to these effluents are carbohydrates, proteins and fats originating from the milk (Kasapgil et al.,1994 and Perle et al.,1995).

While the cheeses have always been a production priority, the main by-product, i.e whey, representing a very high percentage of processed milk, has been greatly neglected in the past, both in terms of characterization and possible use. In fact, whey main use consists in swine feeding if not disposal, with the relative costs of the process, sometimes even outside of compliance with environmental regulations.

As a matter of fact, such wastewaters cannot be simply dismissed, and they require a chemical or mechanical processing, with a significant economic cost.

Among several possible approaches, membrane technologies, and more specifically Reverse 0smosis (R0) technology has been successfully applied for the treatment of dairy wastes (Vourch et al., 2005), and as a technology for concentration and fractionation of whey.

Generally speaking two different strategies can be adopted: the first simply aimed to dismiss the dairy waste minimizing the economic and environmental impact (clean water production + concentrated products), the second considering such wastes as a resource and focused on recovery by-products from the wastewaters in order to increase the economic value of the overall chees production process.

Specifically, whey protein represents one of the most interesting byproducts, although some technical difficulties can arise when the final transformation is not performed in the dairy industry itself, due to the fact that refrigeration is required to preserve their properties.

In this work a membrane treatment approach using reverse osmosis technology is investigated and implemented: the permeate obtained can be reused as clean warm water for cleaning and sanitation of production plants, while concentrated milk proteins are modified by using transglutaminase enzyme obtaining a high temperature resistant fat replacer to be used in different low-fat products like for example mozzarella cheese. 


\section{Materials and methods}

\section{Reverse Osmosis Plant description}

The first part of the work consisted in selecting an appropriate membrane treatment plant to be introduced in a cheese factory (Caseificio Campolongo Srl ), with the aim of producing high quality whey protein and clear water from separation process.

Reverse Osmosis (RO) is a system of concentration of liquid alternative to thermal evaporation systems, with operating costs lower than in conventional evaporators, and an appropriate RO concentration plant was built on skids for easy handling and a more rational layout, equipped with 24 elements polymeric spiral membranes.

The plant was fed from a reservoir operated by a level control automatic system for the whey filling. A centrifugal pump with an installed power of $0.75 \mathrm{~kW}$ was used to collect the serum from the food reservoir of food and to send, after safety filtration using a polypropylene bag filter with a filtration network of 50 microns, into a heat exchanger for inlet temperature control.

The system can work in two temperature conditions: cold $\left(10^{\circ} \mathrm{C}\right.$ $\left.15^{\circ} \mathrm{C}\right)$ or warm $\left(50^{\circ} \mathrm{C}\right)$ operative mode, as working at intermediate temperatures promotes bacterial growth, causing the fouling of the membranes. The serum, after being set to the appropriate temperature in the heat exchanger, was pressurized using a multi-impeller centrifugal pump with an installed capacity of $7.5 \mathrm{~kW}$, controlled by an inverter, and then sent to double multi-impeller centrifugal recirculating pumps with an installed capacity of $4 \mathrm{~kW}$ for each loop on the membranes.

The two pumps ensure the serum to make the loop into the 24 polymeric spiral membranes with a pressure up to 40 bar. The concentrate is then transferred to another tank after a second heat treatment. An automatic control system governs the operation of all devices installed on the system and automatically controls the exercise cycles, as well as membrane rinsing and washing.

Operating conditions are listed in Table 1.

Serum feeding should be pre-filtered on a dry filter, degreased ( $($ to $0,05 \%$ fat final content) at $10^{\circ} \mathrm{C}-15^{\circ} \mathrm{C}$ or $50^{\circ} \mathrm{C}$. In case the system works at low temperature, the plant efficiency is expected to decline in the order of $20-25 \%$.

\section{Protein concentration}

The whey is what remains of the milk as a result of the process of curdling, necessary for the production of dairy products of all kinds. In addition to serum, other liquid waste are generated by the production process of the cheese, like ricotta cheese and butter.

In the considered dairy industry, production data are reported in Table 2.

The quantities of the latter are usually of the order of $20 \%$ of the total liquid waste products, depending on seasonal production of the cheese. The final concentrations of retentate is approximately around $18 \%$ and the permeate presents low values of conductivity (low salt content).

\section{Low-Fat Mozzarella cheese production}

While traditional products like mozzarella are widely present on any market shelf, reducing economic income for the producer due to their saturated market, some low fat cheeses can be sold in niche markets with high added value.

A major problem in low-fat mozzarella cheese production is related to the choice of fat replacer: as a matter of fact, most of industrial fat replacers are not able to preserve their structure at spinning temperature, e moreover they tend to change texture and flavor of the final product. Being mozzarella a well characterized cheese, this would involve a low acceptance from the final consumer. In our approach, whey proteins obtained from R0 concentration and previously treated with an enzymatic process using Transglutaminase (TGase), were used as fat replacer.

Several tests were performed, adding proteins at concentrations gradually higher, starting at $1 \%$ and reaching $10 \%$.

In this work, the low fat mozzarella cheese, with characteristics in line with the traditional mozzarella, is obtained using a skimmed milk with a fat content of $2 \%$ (approximately $50 \%$ less than the initial content). To this milk, suitably heated, is added the curd and whey protein concentrate suitably modified. After $\mathrm{pH}$ stabilization, the coagulation is carried out at a temperature of about $35^{\circ} \mathrm{C}$; when $\mathrm{pH}$ reaches the optimal value for the processing and the spinning is performed.

Subsequent industrial tests have indicated as an optimal percentage the addition of $10 \%$ of the modified proteins, performing mechanical spinning with acceptable results from a point of view of workability of the product.

\section{Chemical Analysis of Low-Fat mozzarella cheese}

Cheese moisture was determined by microwave oven by drying the samples to a constant weight (i.e., $<0.1 \mathrm{mg}$ change over $10 \mathrm{~s}$ ) at $50 \%$ power. Protein and fat contents were determined respectively by Kjeldhal method and according to García-Ayusousing L. E. et al., 1999. Each assay was performed in triplicate.

\section{Instrumental texture analysis of mozzarella cheese.}

Mozzarella cheese's texture Mozzarella was evaluated using an Instron universal testing instrument model no. 5543A (Instron Engineering Corp., Norwood, MA, USA) equipped with a $2 \mathrm{kN}$ load cell in compression mode with a cylindrical probe ( $55 \mathrm{~mm}$ diameter). The instrumental Texture Profile Analysis (TPA) test described by Bourne,1978 was used. The test was configured for analyzing the four TPA parameters, hardness, springiness, chewiness, and cohesiveness. Pre- and post-test speeds were $2.0 \mathrm{~mm} / \mathrm{sec}$, while test speed was 1.0 $\mathrm{mm} / \mathrm{sec}$. Mozzarella was removed from the refrigerator and allowed to heat up at room temperature (1-2 h) and then, three cylinder of $30 \mathrm{~mm}$ diameter were cut from each samples. Samples, prepared as described above, were centered and compressed to $20 \%$ of deformation. All the analyses were performed with at least eight samples per batch.

Table 1. Operating conditions for the RO plant.

\begin{tabular}{lc}
\hline Final water quantity & $\max 2.000 \mathrm{l} / \mathrm{h}$ \\
Working cycle & $\max 10$ hours \\
\hline Concentration ratio & 3 \\
Filtered serum per cycle & $\max 30.000 \mathrm{I}$ \\
\hline Operative pressure & $25-35 \mathrm{bar}$ \\
Temperature & $\max 50^{\circ} \mathrm{C}$ \\
\hline
\end{tabular}

Table 2. Production data.

\begin{tabular}{lc}
\hline Transformed milk & $18000 \mathrm{~kg} /$ day \\
Working days & $300 /$ year \\
\hline Serum quantity & $16000 \mathrm{~kg} /$ day \\
Serum $/$ Milk(\%) & $90 \%$ \\
\hline Low fat serum(\%) & $60 \%$ \\
Scotta (\%) & $20 \%$ \\
\hline
\end{tabular}




\section{Results}

\section{Power consumption}

It was possible to estimate that the specific consumption of electrical energy (absorbed by the processing equipment: equipment, pumps and refrigeration unit) to concentrate whey is equal to $7 \mathrm{kWh} / \mathrm{m}^{3}$, while the specific fuel consumption (used in the boiler to heat the water necessary for the process) is equal to $2 \mathrm{~kg}$ fuel $/ \mathrm{m}^{3}$ of treated serum.

Since on average there are approximately $240 \mathrm{~m}^{3}$ of serum per month, it is estimated an electricity consumption equal to 1680 $\mathrm{kWh} /$ month and a fuel consumption of $480 \mathrm{~kg}$ of fuel per month. The hot operative working condition, as explained in the previous section, it is recommended with respect to the cold working. The proposed approach allowed an annual save of $30 \mathrm{k} €$ respect to the previous system in which an external company was paid for concentrated protein transportation.

\section{Low-fat mozzarella cheese characteristics}

The reduction of fat in Mozzarella cheese often leads to various defects such as rubbery texture, as well as poor meltability and stretchability, principally due to its low moisture. Water is thought to act as a lubricant or plasticizer between the proteins, and in fact it is well known that increasing the ratio of water to cheese proteins makes the cheese softer.

Ismail et al.,2011 suggest the use of denatured whey protein to improve low fat Mozzarella cheese properties by increasing water holding. Di Pierro et al., 2010 used enzyme Transglutaminase (TGase) to produce a novel, so-called "crosslinked cheese" with increased water content and cheese yield. In this work we have used TGase to crosslink the two times concentrated whey proteins in order to produce covalent micro-particulates. Afterwards the TGase-modified proteins were added to defatted milk at a concentration of $10 \%$ (MS-10) and $12 \%$ (MS-12) $(\mathrm{v} / \mathrm{v})$ before the manufacture of Mozzarella cheese.

We compared such new product with conventional Mozzarella (control). It is possible to note from Table 3 that the water holding in Mozzarella cheese is directly correlated to the amount of TGase-treated whey added.

However, only in Mozzarella cheese obtained with $10 \%$ of TGasetreated whey showed a significant increase of protein content. These results can be explained by hypothesizing the increase of serum bound to the gel network reinforced by additional covalent bonds, and the incorporation of casein fines or whey proteins into the gel network, due to the activity of the enzyme added together with the treated whey (Di Pierro et al., 2010;Sayadi et al.,2013).

It is well known that textural properties (hardness, cohesiveness, springiness, and chewiness) are important functional properties of Mozzarella and any attempt to reduce the fat content of Mozzarella have to take into account these aspects. We have compared the textural properties of Mozzarella cheese using a Texture Profile Analyses (TPA). Results reported in Table 4 showed no significant differences in respect to springiness, chewiness and cohesiveness were observed between MS-10 and control Mozzarella cheeses, while hardness significantly increased, probably due to the TGase crosslinks which increase water retention. On the contrary, MS-12 Mozzarella cheeses showed a significant reduction of both hardness and chewiness, suggesting that a higher number of crosslinks is responsible for a greater amount of serum retained in this type of Mozzarella cheese which increased the structure volume providing a softer texture. In fact, it is well known that increasing the ratio of water to cheese proteins makes the cheese softer. Water is thought to act as a lubricant or plasticizer between the protein molecules, making the cheese more pliable (Glicksman, 1991;
Table 3. Effect of the addition of TGase-treated whey on chemical composition of Mozzarella cheese.

\begin{tabular}{lccc} 
Mozmarella cheese & $\begin{array}{c}\text { Water content } \\
(\%)\end{array}$ & $\begin{array}{c}\text { Protein content } \\
(\% \mathrm{DM})\end{array}$ & $\begin{array}{c}\text { Fat } \\
(\% \mathrm{DM})\end{array}$ \\
Control & $63.18 \pm 1.2$ & $16.03 \pm 0.35$ & $16.71 \pm 1.2$ \\
MS-10 & $66.26 \pm 1.9$ & $18.23 \pm 0.68$ & $9.40 \pm 0.9$ \\
\hline MS-12 & $69.28 \pm 1.3$ & $17.97 \pm 0.92$ & $9.72 \pm 2.2$ \\
\hline
\end{tabular}

Values are mean \pm standard deviation (SD). DM, Dry Matter.

Table 4. Effect of the addition of TGase-treated whey on rheological properties of Mozzarella cheese.

\begin{tabular}{lcccc} 
& $\begin{array}{c}\text { Hardness } \\
(\mathbf{N})\end{array}$ & $\begin{array}{c}\text { Springiness } \\
(\mathbf{m m})\end{array}$ & $\begin{array}{c}\text { Chewiness } \\
(\mathbf{N} \text { mm })\end{array}$ & Cohesiveness \\
Control & $70.35 \pm 13.52^{\mathrm{a}}$ & $20.2 \pm 1.5^{\mathrm{a}}$ & $913.4 \pm 155.4^{\mathrm{a}}$ & $0.63 \pm 0.04^{\mathrm{a}}$ \\
MS-10 & $80.13 \pm 7.07^{\mathrm{b}}$ & $19.9 \pm 4.5^{\mathrm{a}}$ & $847.3 \pm 232.7^{\mathrm{a}}$ & $0.53 \pm 0.06^{\mathrm{a}}$ \\
\hline MS-12 & $47.12 \pm 8.35^{\mathrm{c}}$ & $20.7 \pm 2.2^{\mathrm{a}}$ & $565.6 \pm 163.7^{\mathrm{b}}$ & $0.57 \pm 0.04^{\mathrm{a}}$ \\
\hline $\begin{array}{l}\text { Values are mean } \pm \text { standard deviation (SD). Mean followed by the same letters are not significant } \\
\text { (Tukey-Kramer test } \mathrm{p}<0.05)\end{array}$
\end{tabular}

Tunick, 1991). Our results suggest that $10 \%$ is the highest amount of TGase-treated whey that do not affect the rheological properties of Mozzarella cheese. Moreover, pre-treatment of whey with the enzyme TGase is an effective strategy to produce defatted Mozzarella cheese with textural properties comparable to the normal one.

\section{Conclusions}

The proposed approach couple a standard reverse osmosis membrane technology with an advanced enzymatic treatment of whey protein to obtain a high value secondary product which can be used as a fat replacer. This product can be locally used to produce high value salutistic cheeses, like a low fat mozzarella cheese. The low-fat mozzarella cheese was subjected to sensory analysis and did not show significant differences from the traditional mozzarella. It seems to preserve the same taste and texture of the classic mozzarella produced by Campolongo Srl but with $50 \%$ less fat, and the product is going to be soon commercialized.

A significant economic saving was obtained locally using concentrated whey proteins, without considering the added value of low-fat mozzarella cheese. Moreover, tests are currently performed to introduce whey modified proteins in other cheese typologies.

\section{References}

Bourne, M.-C. 1978. Texture profile analysis. Food Technology, 32 (7), $62-66,72$.

Di Pierro, P., Mariniello, L., Sorrentino, A., Gosafatto, C. V. L., Chianese, L., \& Porta, R., 2010. Transglutaminase induced chemical and rheological properties of cheese. Food Biotechnology, 24, 107-120.

García-Ayuso L. E., Velasco J., Dobarganes M. C. and Luque de Castro M. D.,1999. Accelerated Extraction of the Fat Content in Cheese Using a Focused Microwave-Assisted Soxhlet Device. J. Agric. Food Chem., 47 6: 2308. 
Glicksman, M., 1991. Hydrocolloids and the search for the "Oily Grail". J. Food Technol. 10:94.

Ismail M., Ammar E.T., and El-Metwally R., 2011. Improvement of low fat mozzarella cheese properties using denatured whey protein. International Journal of Dairy Technology, 64 (2): 207.

Kasapgil B, Anderson G.K., Ince 0.,1994. An investigation into the pretreatment of dairy wastewater prior to aerobic biological treatment. Water Sci Technol;29:205-12.

Orhon D, Gorgun E, Germirli F, Artan N.,1993. Biological treatability of dairy wastewaters. Water Res. ;27:625-33.

Perle M, Kimchie S, Shelef G.,1995, Some biochemical aspects of the anaerobic degradation of dairy wastewater. Water Res.,29:1549-54.

Sayadi A., Madadlou A., Khosrowshahi A.,2013. Enzymatic cross-linking of whey proteins in low fat Iranian white cheese. International Dairy Journal, 29, 88-92

Tunick, M. H., Mackey K. L., Smith P. W., and Holsinger V. H.,1991. Effects of composition and storage on the texture of Mozzarella cheese. Neth. Milk Dairy J. 45:117.

Vourch, M., Balannec, B., Chaufer, B., Dorange, G., 2005. Nanofiltration and reverse osmosis of model process waters from the dairy industry to produce water for reuse, Desalination, 172, 3:245-256. 